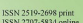

НАУКОВИЙ ВІСНИК

If

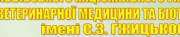

cientific mesenenger of Lviv National University of

Veterinary

and

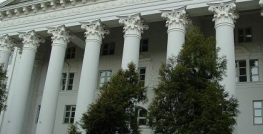

Том 23 № 94 2021
Науковий вісник Яьвівського національного університету ветеринарної медицини та біотехнологій імені С.3. Гжицыкого. Серія: Сільськогосподарські науки

\section{Scientific Messenger of Lviv National University of Veterinary Medicine and Biotechnologies. Series: Agricultural sciences}

https://nvlvet.com.ua/index.php/agriculture

UDC 638.19:638.1:633.31

\title{
Prophylaxis of digestion disorders in honey bees
}

\author{
Y. Kovalskyi, V. Fedak, L. Kovalska, A. Druzhbiak, Y. Vovkun
}

Stepan Gzhytskyi National University of Veterinary Medicine and Biotechnologies Lviv, Ukraine

Article info

Received 10.02.2021

Received in revised form 11.03.2021

Accepted 12.03.2021

Stepan Gzhytskyi National University of Veterinary Medicine and Biotechnologies Lviv, Pekarska Str., 50, Lviv, 79010, Ukraine.

Tel.:+38-067-938-54-13 E-mail:prikarpatmed@ukr.net
Kovalskyi, Y., Fedak, V., Kovalska, L., Druzhbiak, A., \& Vovkun, Y. (2021). Prophylaxis of digestion disorders in honey bees. Scientific Messenger of Lviv National University of Veterinary Medicine and Biotechnologies. Series: Agricultural sciences, 23(94), 61-64. doi: 10.32718/nvlveta9412

The stability of the intestinal immunity of the honey bee depends on the effects of various toxic substances. Especially when detecting some infectious diseases in apiaries, when using various antibiotics. The aim of the study was to study the effect of oxytetracycline on the morphological parameters of enterocytes of the midgut and the microbiological pool of the intestine. To do this, 10 days after the last treatment, for the next five days, 20 experimental bees were selected from each family, immobilized and the midgut dissected. The study of the folds of the midgut was performed on paraffin sections. The study was performed histopreparations, which were obtained at a distance of $5 \mathrm{~mm}$ from the beginning of the midgut. Sequentially arranged 10 folds were chosen for measurement. Morphometric parameters of enterocytes were obtained by measuring their height, width and area. It has been studied that three sprays of working solution of oxytetracycline at a dose of $900 \mathrm{mg}$, per family, with an interval of two days, adversely affects the morphological parameters of enterocytes of the midgut. On the segmental section, in the cranial direction, there is a decrease in the number of folds of the epithelium per unit area of the intestine. At the same time, the area of enterocytes is smaller by $14.9 \%$ compared to the epithelial cells of control bees. For microbiological examination of the intestine was carried out sowing on nutrient media, followed by counting bacteria. It was investigated that the intestinal microorganisms of bees are represented by both gram-positive (Bacillus, Streptococcus, Staphylococcus) and gram-negative (Enterobacter, Escherichia, Mikrococus) bacteria, as well as fungi and yeasts. At the same time, enterobacteria (Enterobacter aerogenes and Escheriichia coli) and staphylococci (Staphylococcus varneri) are dominant in the microbiocenosis. In the intestines of bees, where the antibiotic got, no $100 \%$ destruction of bacteria was detected, but changes were still observed. And they are associated with a decrease in their absolute number. The most negative effects were found for Bifidobacterium and Lactobacillus. In May, the maximum concentration of Lactobacillus plantarum was detected, which is normally $3.3 \mathrm{lg}$ CFU/g. In September and October, some lactic acid bacteria are completely absent in the intestines of bees.

Key words: honey bees, digestion, xenobiotics, intestinal tract, microbiocenosis, lactic acid bacteria.

\section{Профілактика розладів травлення у медоносних бджіл}

\author{
Ю. В. Ковальський, В. В. Федак, Л. М. Ковальська, А. Й. Дружбяк, Я. М. Вовкун
}

Львівський національний університет ветеринарної медицини та біотехнологій імені С. 3. Гжицького, м. Львів, Украӥна

Стабільність кишкового імунітету медоносної бджоли залежить від впливу різноманітних токсичних речовин. Особливо під час виявлення деяких інфекційних хвороб на пасіках, коли застосовують різноманітні антибіотики. Метою роботи було вивчення впливу окситетрацикліну на морфологічні показники ентерочитів середньої кишки та мікробіологічний пул кишечника. Для изього через 10 діб після останньої обробки, протягом наступних п'яти днів відбирали піддослідних бджіл у кількості по 20 особин від кожної сім'ї, знерухомлювали їх та відпрепаровували середню кишку. Вивчення складок середньої кишки проводили на парафінових зрізах. Дослідженню підлягали гістопрепарати, одержані на відстані 5 мм від початку середньої кишки. Для вимірювання обирали послідовно розташовані 10 складок. Морфометричні показники ентероцитів отримували шляхом вимірювання їх висоти, иирини 
та площі. Досліджено, щзо трикратне обприскування робочим розчином окситетрацикліну в дозі 900 мг у розрахунку на одну сім'ю, з інтервалом у дві доби, негативно впливає на морфологічні показники ентерочитів середної кишки. На сегментальному зрізі, в краніальному напрямку, спостерігається зменшення кількості складок епітелію у розрахунку на одиницю площі кишки. При цьому площза ентероцитів є меншою на 14,9\% порівняно з показниками клітин епітелію контрольних бджіл. Для мікробіологічного дослідження кишечника здійснювали висів на поживні середовища з подальшим підрахунком бактерій. Досліджено, щчо мікроорганізми кишечника бджіл представлені як грампозитивними (Bacillus, Streptococcus, Staphylococcus), так $i$ грамнегативними (Enterobacter, Escherichia, Mikrococus) бактеріями, а також плісневими грибаии і дріжджами. При иььому, домінантними у мікробіоценозі є ентеробактерії (Enterobacter aerogenes i Escheriichia coli) i стафілококи (Staphylococcus varneri). V кишечнику бджіл, де потрапив антибіотик, не виявлено $100 \%$ знищення бактерій, але зміни все ж спостерігались. I вони пов'язані зі зменшенням їх абсолютної кількості. Найбільш негативний вплив було виявлено щодо Bifidobacterium та Lactobacillus. У травні виявлено максимальну концентрацію Lactobacillus plantarum, яка у нормі становить 3,3 lg КУО/.. У вересні та жовтні в кишечнику бджіл деякі молочнокислі бактерії були відсутні.

Ключові слова: медоносні бджоли, травлення, ксенобіотики, кищковий тракт, мікробіоценоз, молочнокислі бактерії.

\section{Вступ}

Продуктивність бджолиних сімей значним чином залежить від здатності організму медоносних бджіл протидіяти впливу різноманітних патогенних факторів. Існують припущення щодо зниження рівня імунітету бджіл за впливу різноманітних чинників, у тому числі пестицидів та інших токсичних речовин (Engel et al., 2012). При цьому науковці досліджують тривалість життя комах, поведінкові особливості, показники відтворювальної здатності та низку інших факторів (Raymann et al., 2017; Kovalskyi et al., 2018; Kovalchuk et al., 2019; Vishchur et al., 2019).

Одним 3 основних компонентів раціону бджіл є квітковий пилок. Його хімічний склад різноманітний і залежить переважно від ботанічного походження. Споживаючи пилок, організм отримує незамінні амінокислоти, жири, вітаміни та мінеральні речовини (Taranov, 1986). Більшість 3 них засвоюється у середній кишці. Біологічна цілісність структурних компонентів кишки позитивно корелює 3 показниками засвоюваності корму. Однак у кишковому тракті залишаються неперетравленими такі компоненти клітинної стінки пилкового зерна, як целюлоза, геміцелюлоза, пектин. У літературі зустрічається безліч повідомлень про те, що в дистальному відділі кишечника процесам травлення сприяють різноманітні мікроорганізми. У кишечнику медоносної бджоли домінує невелика кількість симбіотичної мікрофлори (Engel et al., 2012). Вона складається 3 аеробних і анаеробних мікроорганізмів, які представлені грамнегативними, грампозитивними бактеріями та грибами (Martinson et al., 2012; Olofsson et al., 2014; Lee et al., 2015; Rokop et al., 2015; Raymann et al., 2017). Ці мікроорганізми своєю чергою впливають на ендокринні сигнали, імунну функцію та стійкість до збудників хвороб. Кишковий тракт медоносної бджоли належить до органів імунної системи (Bonilla-Rosso \& Engel, 2018).

Деякі пасічники, виявивши клінічні ознаки різної етіології, а також з профілактичною метою використовують антибактеріальні препарати із групи тетрациклінів. Проте під впливом цих препаратів у розвитку епітелію кишечника медоносної бджоли та його мікробіоценозі можуть відбуватися значні зміни.

Метою дослідження було вивчення впливу деяких антимікробних препаратів на морфологічні показники ентероцитів середньої кишки та мікробіологічний пул кишечника.

\section{Матеріал і методи досліджень}

Робота виконана впродовж 2018-2020 років на кафедрі технології виробництва та переробки продукції дрібних тварин Львівського національного університету ветеринарної медицини та біотехнологій імені С. 3. Гжицького. Дослідження проводилися у відділі бджільництва кафедри, а також у лабораторії кафедри нормальної та патологічної морфології і судової ветеринарії. На першому етапі проведено дослідження впливу окситетрацикліну на морфологічні показники епітелію середньої кишки. Другий етап передбачав вивчення мікробіоценозу кишкового тракту. Доза препарату становила 900 мг у розрахунку на одну сім’ю. Застосовували трикратне обприскування робочим розчином з інтервалом у дві доби. У контрольній групі були клінічно здорові бджолині сім'ї.

Через 10 діб після останньої обробки протягом наступних п’яти днів відбирали піддослідних бджіл у кількості по 20 особин від кожної сім’ї, усипляли їх та відпрепаровували середню кишку. Вивчення складок середньої кишки проводили на парафінових зрізах, виготовлених за стандартними методиками зі зразків стінок кишки, відібраних із піддослідних сімей і зафіксованих у фіксаторі Буена (Pishak, 2008). Дослідженню підлягали гістопрепарати, які одержані на відстані 5 мм від початку середньої кишки. Проміри довжини складок середньої кишки здійснювали від базальної мембрани до апікального краю, включно з мікроворсинками. Для вимірювання обирали послідовно розташовані 10 складок. Морфометричні показники ентероцитів отримували шляхом вимірювання їхньої висоти, ширини та площі.

Для мікробіологічного дослідження кишечник поміщали в стерильний бюкс і зважували. Після цього ретельно гомогенізували в стерильній фарфоровій ступці в 1 \% розчині пептонної води у співвідношенні $1: 10$ і готували ряд розведень з $0,1 \%$ агар-агаром. 3 отриманих розчинів за допомогою градуйованої піпетки на поверхню селективних середовищ робили посіви в об'ємі 0,025 мл у вигляді трьох ізольованих крапель. Через 72 год інкубації за температури $37^{\circ} \mathrm{C}$ здійснювали підрахунок колоній, які виросли. Кількість мікроорганізмів у розрахунку на 1 г вмісту кишечника розраховували за методикою Бочкова I. А. (Bochkov et al., 1989). 


\section{Результати та їх обговорення}

Поверхня середньої кишки у піддослідних особин природного “вишневого” кольору, без видимих змін. Слизова оболонка представлена одношаровим епітелієм. При цьому за рахунок безлічі складок збільшується площа поверхні всмоктування.

Корм, який перебуває в ендоперетрофічному просторі, утримується перетрофічними мембранами. Причому кожна порція корму обволікається іншою мембраною. Очевидно, пласти перетрофічної мембрани, які продукуються епітеліальними клітинами, покривають кожну частину корму в міру їі надходження. На гістопрепаратах чітко виявлено безліч пилкових зерен.

Функція переднього відділу середньої кишки полягає у секреції травних ферментів (в основному це протеази і ліпази). Ці ферменти продукують ентероцити. Цитоплазма ентероцитів дослідної групи_заповнена дрібними і щільними однорідними включеннями, але неушкоджена і має чіткі межі. На сегменталь- ному зрізі, в краніальному напрямку, спостерігається зменшення кількості складок епітелію у розрахунку на одиницю площі кишки. Площа ентероцитів на 14,9 \% менша порівняно $з$ клітинами епітелію контрольних бджіл.

На стадії імаго епітелій підтримується за рахунок клітин, які ростуть і починають дозрівати у криптах. Проведені дослідження вказують, що потрапляння тетрацикліну до вмісту кишечника змінює реплікативну активність ентероцитів. Своєю чергою це впливало на показники швидкості проліферації.

Таким чином, результати проведених досліджень вказують на те, що деякі ксенобіотики, які потрапляють до травної системи бджіл, можуть мати негативний ефект, що проявляється зниженням ступеня засвоєння поживних речовин корму. Це своєю чергою призводить до загального зниження рівня імунної системи та, як наслідок, спричиняє виникнення різноманітних захворювань кишкового тракту. Особливо небезпечне це явище на пасіках, де протягом минулих років були виявлені спалахи нозематозу.

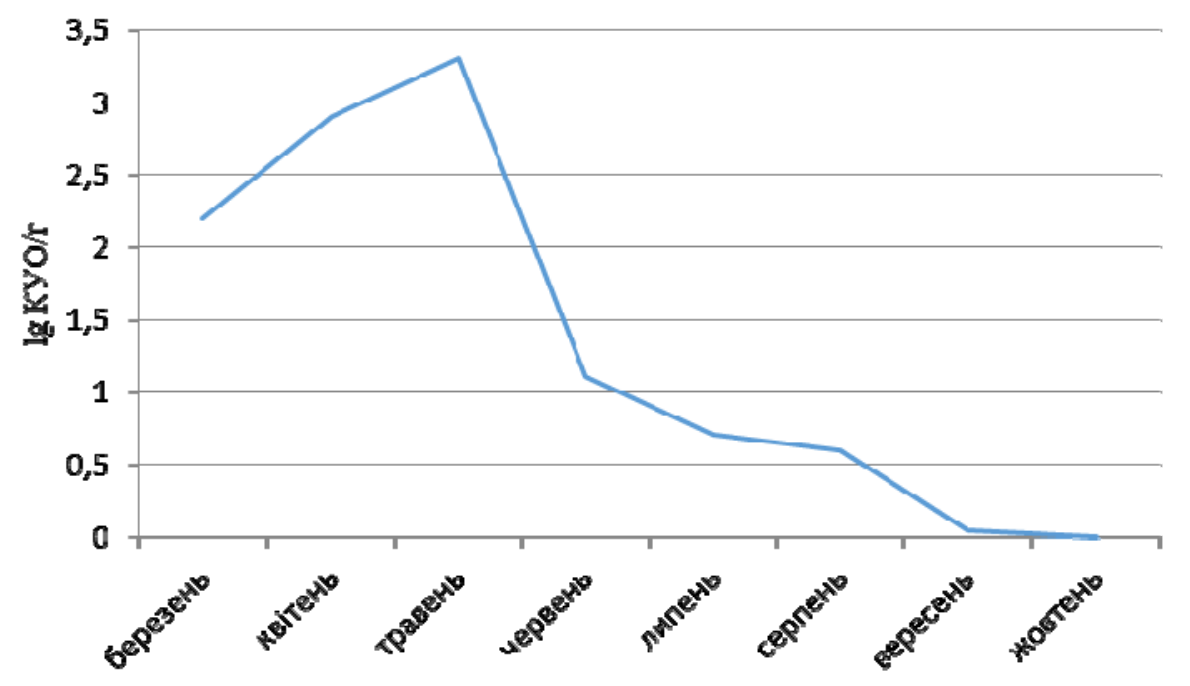

Рис. 1. Динаміка Lactobacillus plantarum кишкового тракту медоносної бджоли в нормі, $\lg$ КУО/г

3 ідентифікованих мікроорганізмів кишечника бджоли виявлено як грампозитивні (Bacillus, Streptococcus, Staphylococcus), так і грамнегативні (Enterobacter, Escherichia, Mikrococus) бактерії, а також плісневі гриби і дріжджі. При цьому домінантними у мікробіоценозі є ентеробактерії (Enterobacter aerogenes i Escheriichia coli) і стафілококи (Staphylococcus varneri).

У кишечнику бджіл, де потрапив антибіотик, не виявлено $100 \%$ знищення бактерій, але зміни все ж є. I вони пов'язані із зменшенням їх абсолютної кількості. Найбільш негативний вплив було виявлено щодо Bifidobacterium та Lactobacillus. Згідно $з$ даними літератури, серед хвороб бджіл суттєву роль займають захворювання з кишковою етіологією (Olofsson et al., 2014; Rokop et al., 2015).

Кількість мікроорганізмів у кишковому тракті медоносної бджоли різна. Вона залежить від впливу деяких факторів. У задньому відділі травного тракту їх кількість є максимальною. У дорослих бджіл їхня концентрація, зокрема, залежить від сезону року.
Поряд з цим припускаємо, що характер живлення має найбільш вагомий вплив на кількість молочнокислих бактерій у кишковому тракті бджоли. Присутність цих мікроорганізмів виявлено у весняно-літній період. Причому найбільша їх кількість спостерігається у квітні i травні. При дослідженні наявності Lactobacillus plantarum у травні виявлено максимальну кількість - 3,3 $\lg$ КУО/г. Саме у цей місяць матки відкладають 1500-1600 яєць на добу. У цей період весни для вирощування розплоду та продукування маточного молочка молоді бджоли споживають пергу. Дозрівання перги у гнізді супроводжується розвитком молочнокислих бактерій. Тому при іiі споживанні у кишковому тракті бджіл виявляють бактерії, які присутні у перзі. Протягом червня і липня виявлено різке зниження кількості лактобактерій. Особливо бідний у кількісному плані кишковий мікробіоценоз серпневих бджіл.

Дослідження щодо їх наявності в інші періоди року підтверджують той факт, що у вересні й жовтні, при підготовці до періоду гіпобіозу, такий вид як 
Laktobacillus plantarum відсутній у всіх піддослідних особин. Тому припускаємо, що застосування у живленні бджіл пробіотичних препаратів доцільне тільки після заміни зимової генерації комах.

Оскільки рівень обсіменіння вулика позитивно корелює 3 мікробіотою кишечника, постає завдання домогтися зменшення кількості бактерій і грибів, які можуть стати причиною виникнення різних хвороб. Зниження чисельності ентеробактерій можна досягнути шляхом проведення низки превентивних заходів, у тому числі використовуючи дезінфекцію вуликів і стільників. Для цього рекомендуємо використовувати препарат “Екоцид C”. Цей препарат має широкий спектр антимікробної дії щодо бактерій та вірусів. Тому його застосовують для профілактичної та вимушеної (поточної і заключної) дезінфекції.

\section{Висновки}

Застосування окситетрацикліну може мати негативні наслідки у розвитку структурних компонентів слизової оболонки середньої кишки. При цьому антибактеріальний препарат негативно впливає на наявність корисних мікроорганізмів, у тому числі Bifidobacterium та Lactobacillus.

\section{References}

Bochkov, I. A., Trofimova, O. D., \& Darbeeva, O. S. (1989). Uproshhenna metodika podscheta mikroorganizmov pri izuchenii autoflori cheloveka. Laboratornoe delo, 6, 43-47 (in Russian).

Bonilla-Rosso, G. \& Engel, P. (2018). Functional roles and metabolic niches in the honey bee gut microbiota. Curr. Opin. Microbiol, 43, 69-76. doi: 10.1016/j.mib.2017.12.009.

Engel, P., Martinson, V. G., \& Moran, N. A. (2012). Functional diversity within the simple gut microbiota of the honey bee. Proc. Natl. Acad. Sci., 109(27), 11002-11007. doi: 10.1073/pnas.1202970109.

Kovalchuk, I., Dvylyuk, I., Lecyk, Y., Dvylyuk, I., \& Gutyj, B. (2019). Physiological relationship between content of certain microelements in the tissues of different anatomic sections of the organism of honey bees exposed to citrates of argentum and cuprum. Regulatory Mechanisms in Biosystems, 10(2), 177 181. doi: 10.15421/021926.

Kovalskyi, Yu., Gucol, A., Gutyj, B., Sobolev, O., Kovalska, L., \& Mironovych, A. (2018). Features of his- tolism and hystogenesis in the vital temperature range in the organism of honey bee (Apis mellifera L.) in the postembrional period. Ukrainian Journal of Ecology, 8(2), 301-307. doi: 10.15421/2018 342.

Lee, F. J., Rusch, D. B., Stewart, F. J., Mattila, H. R., \& Newton, I. L. (2015). Saccharide breakdown and fermentation by the honey bee gut microbiome. Environ. Microbiol, 17(3), 796-815. doi: 10.1111/14622920.12526.

Martinson, V. G., Moy, J., \& Moran, N. A. (2012). Establishment of characteristic gut bacteria during development of the honeybee worker. Appl. Environ. Microbiol, 78(8), 2830-2840. doi: 10.1128/AEM.0781011.

Olofsson, T. C., Alsterfjord, M., Nilson, B., Butler, E., \& Vasquez, A. (2014). Lactobacillus apinorum sp. nov., Lactobacillus mellifer sp. nov., Lactobacillus mellis sp. nov., Lactobacillus melliventris sp. nov., Lactobacillus kimbladii sp. nov., Lactobacillus helsingborgensis sp. nov. And Lactobacillus kullabergensis sp. nov., isolated from the honey stomach of the honeybee Apis mellifera. Int. J. Syst. Evol. Microbiol, 64(9), 3109-3119. doi: 10.1099\%2Fijs.0.059600-0.

Pishak, V. P. (2008). Histolohiia z osnovamy histolohichnoi tekhniky. Pidruchnyk. Kyiv: KONDOR (in Ukrainian).

Raymann, K., Shaffer, Z. \& Moran, N. A. (2017). Antibiotic exposure perturbs the gut microbiota and elevates mortality in honeybees. PLoS Biol, 15, e2001861. doi: 10.1371/journal.pbio.2001861.

Rokop, Z. P., Horton, M. A., \& Newton, I. L. (2015). Interactions between cooccurring lactic acid bacteria in honey bee hives. Appl. Environ. Microbiol, 81(20), 7261-7270. doi: 10.1128/AEM.01259-15.

Taranov, G. F. (1986). Korma i kormlenie pchel. M. (in Russian).

Vishchur, V. Y., Gutyj, B. V., Nischemenko, N. P., Kushnir, I. M., Salata, V. Z., Tarasenko, L. O., Khimych, M. S., Kushnir, V. I., Kalyn, B. M., Magrelo, N. V., Boiko, P. K., Kolotnytskyy, V. A., Velesyk, T., Pundyak, T. O., \& Gubash, O. P. (2019). Effect of industry on the content of fatty acids in the tissues of the honey-bee head. Ukrainian Journal of Ecology, 9(3), 174-179. URL: https://www.ujecology.com/ abstract/effect-of-industry-on-the-content-of-fatty-acidsin-the-tissues-of-the-honeybee-head-44509.html. 